\title{
Sikap Muslim Terhadap Wabah Covid-19 Dalam Perspektif Maqashid Syari'ah
}

\author{
Hambali \\ Universitas Islam Negeri Raden Fatah Palembang \\ E-mail: hambali_uin@radenfatah.ac.id
}

\begin{abstract}
The outbreak of the Covid-19 virus which has become a global pandemic has led to a new policy to avoid spreading and transmitting the virus. One of them is the worship policy for Muslims which is responded by MUI and Hai'ah Kibar Ulama Al-Azhar. This study aims to determine the role of Maqashid Shari'ah to find out the purpose of the existence of a law, one of which issued by scholars in dealing with the current emergency conditions. In the context of the covid-19 virus outbreak, eliminating Friday prayers and congregational prayers is a dharuriyat case (primary), because the implementation of the worship raises a crowd that has the potential to cause transmission of the virus, the dharuriyat case is the benefit that must be maintained, as the essence of the Maqashid Sharia.
\end{abstract}

Keywords: Maqshid Syari'ah, Covid-19, Friday prayers and congregational prayers

\section{Pendahuluan}

Saat ini dunia sedang ramai dengan adanya wabah penyakit corona, terhitung sejak tanggal 29 Maret tahun 2020 terdapat 683.694 orang yang tersebar di seluruh dunia terkena wabah penyakit ini dan menyebabkan kematian sebanyak 146.396, angka tersebut diperkirakan akan terus mengalami kenaikan. Maka dari itu, banyak negara termasuk Indonesia telah menetapkan berbagai kebijakan kepada warganya agar terhindar dari wabah penyakit itu salah satunya adalah Lockdown (karantina wilayah) dan Social distancing (menjaga jarak sosial). Hal tersebut dilakukan karena penyakit tersebut dapat menular dari orang yang terinfeksi kepada orang yang tidak terinfeksi, untuk itu dengan menjaga jarak aman dan menghindari kerumunan dapat mengurangi resiko tertular penyakit tersebut.

Begitu juga dengan para ulama, termasuk MUI yang mengeluarkan fatwa Nomor 14 Tahun 2020 yang menetapkan tata cara penyelenggaraan ibadah dalam situasi wabah Covid-19. Fatwa tersebut dibuat bertujuan supaya para umat Islam dapat melaksanakan ibadah dengan baik sesuai dengan protokol kesehatan yang telah ditetapkan guna menghindari penyebaran virus tersebut. Fatwa tersebut diantaranya menetapkan bahwa orang yang telah positif terkena virus tersebut wajib menjaga dan mengisolasi diti agar tidak menularkan virus tersebut kepada orang lain. Kemudian apabila orang tersebut laki-laki, maka shalat jumatnya dapat digantikan dengan shalat dhuhur dirumahnya. Fatwa lain yaitu, bagi orang yang telah terinfeksi virus Covid-19 diharamkan untuk melaksanakan ibadah yang berpotensi mengakibatkan penularan 
virus terhadap orang lain, seperti shalat berjamaah di masjid, menghadiri pengajian, dan tabligh akbar.

Hai'ah Kibar Ulama Al-Azhar juga turut merespon adanya kondisi darurat yang diakibatkan virus Covid-19 dengan mengeluarkan sejumlah pernyataan, salah satunya yaitu anjuran untuk menjaga dan melindungi jiwa serta mencegah dari segala hal yang membahayakan adalah hal yang penting utama dalam prinsip Maqashid Syariah. Maka Hai'ah Kibar Ulama Al-Azhar sebagai lembaga yang memiliki otoritas dalam memberikan penjelasan hukum syar'I yang berkaitan dengan berbagai permasalahan di penjuru dunia memberikan fatwa boleh untuk tidak melaksanakan shalat jumat dan shalat jamaah di masjid selama wabah masih berlangsung untuk mencegah penyebaran dan penularan virus Covid-19 di masyarakat.

Dari uraian tersebut, maka penulis tertarik untuk membahas bagaimana implemantasi Maqashid Syariah dalam menghadapi wabah Covid-19 dengan mengkaji fatwa-fatwa ulama yang telah dijelaskan sebelumnya.

\section{Memahami Makna Maqashid al-syari'ah}

Maqashid al-syari'ah terdiri dari dua kata, yaitu maqashid dan syari'ah. Kata maqashid merupakan bentuk jama' dari maqashad yang berarti maksud dan tujuan, sedangkan syari'ah adalah hukum-hukum Allah yang ditetapkan untuk manusia kemudian dijadikan pedoman untuk meraih kebahagiaan hidup di dunia maupun di akhirat. Untuk itu, maqashid al-syari'ah adalah kandungan nilai yang menjadi tujuan adanya syariat hukum. Dapat diartikan pula bahwa maqashid al-syaria'ah adalah tujuan-tujuan yang hendak dicapai dari suatu penetapan hukum. ${ }^{1}$

Para pakar ilmu ushul fikih merumuskan maqashid al-syari'ah dengan maksud dan tujuan yang dikehendaki syara' dalam mensyariatkan suatu hukum guna mewujudkan kemaslahatan umat manusia. Maqashid al-syari'ah di kalangan ulama ushul fikih juga disebut dengan asrar asy-syari'ah, yang artinya adalah rahasiarahasia yang ditetapkan oleh syara' yang berada di balik suatu hukum, yaitu berupa kemaslahatan bagi umat manusia, baik di dunia maupun akhirat. Para ulama sepakat bahwa dalam setiap hukum yang ditetapkan oleh Allah swt pasti mengandung kemaslahatan bagi hamba-Nya, baik kemaslahatan yang bersifat duniawi dan kemaslahatan yang bersifat ukhrawi. Maka dari itu, setiap mujtahid dalam mengistinbathkan hukum dari suatu kasus yang sedang dihadapi, harus sesuai dengan tujuan-tujuan syara' dalam mensyariatkan hukum, sehingga hukum yang ditetapkan tersebut dapat mendatangkan kemaslahatan bagi kehidupan manusia. ${ }^{2}$

Wahbah al-Zuhaili mendefinisikan maqashid al-syari'ah yaitu nilai-nilai dan sasaran syara' yang terkandung dalam sebagaian besar dari hukum-hukum-Nya. Nilai-nilai dan sasaran-sasaran itu diartikan sebagai tujuan dan rahasia syari'ah, yang ditetapkan oleh al-syari' dalam setiap ketentuan hukum. Selanjutnya, Yusuf al-Qardhawi

${ }^{1}$ Ghofar Shidiq, “Teori Maqashid Al-Syari'ah Dalam Hukum Islam,” Sultan Agung 25, no. 118 (2009): 117-30.

${ }^{2}$ Nilda Susilawati, "Stratifikasi Al-Maqasid Al-Khamsah Dan Penerapannya Dalam AlDharuriyat, Al-Hajiyat, Al-Tahsiniyat," Mizani 9, no. 1 (2015): 137-50.

Published by:

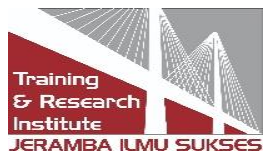


mendefinisikan maqashid al-syari'ah sebagai tujuan yang menjadi sasaran teks dan hukum-hukum particular untuk diwujudkan dalam kehidupan manusia. Baik berupa perintah, larangan, dan kebolehan untuk individu, keluarga, jama'ah, dan umat, atau disebut juga dengan hikmat-hikmat yang menjadi tujuan ditetapkannya hukum, baik yang diharuskan agama atau tidak. Karena dalam setiap hukum yang disyari'atkan Allah kepada hamba-Nya pasti terdapat tujuan mulia atau hikmat yang ada di balik suatu hukum. ${ }^{3}$

Secara garis besar, para ulama memberikan gambaran tentang teori Maqashid Syariah yaitu bahwa Maqashid Syariah harus berpusat dan bertumpu dalam lima pokok kemaslahatan yaitu: kemaslahatan agama (hifz al-din), kemaslahatan jiwa (hifz al-nafs), kemaslahatan akal (hifz al-aql), kemaslahatan keturunan (hifz al-nasl) dan kemaslahatan harta (hifz al-mal). Dalam setiap tingkatannya mempunyai klasifikasi tersendiri, yaitu peringkat pokok/primer (dharuriyyat), peringkat kebutuhan/sekunder (hajiyyat), dan peringkat pelengkap/tersier (tahsiniyyat). Dalam penetapan hukumnya, urutan peringkat ini akan memperlihatkan tingkatan kepentingannya ketika bertentangan dalam kemaslahatannya. Peringkat dharuriyyat menduduki tempat pertama, kemudian hajiyyat mendahului peringkat tahsiniyyat. Dari sini, dapat diartikan bahwa peringkat ketiga melengkapi peringkat kedua dan peringkat pertama dilengkapi oleh peringkat kedua. ${ }^{4}$

\section{Implementasi Maqashid Syari’ah dalam Menghadapi Virus Covid-19}

Sebagaimana yang telah dijelaskan sebelumnya bahwa beberapa ulamandi dunia diantaranya MUI dan Hai'ah Kibar Ulama Al-Azhar telah mengeluarkan berbagai fatwa guna menghadapi wabah virus Covid-19. Kebanyakan dari fatwa tersebut beberapa diantaranya menuai pro dan kontra lalu bagaimana implementasi Maqashid al-Syari'ah dalam pengambilan fatwa ini dan implementasi Maqashid al-Syari'ah dalam menghadapi wabah virus Covid-19.

Ha'iah Kibar Ulama Al-Azhar menyampaikan Fatwa tentang bolehnya

negara atau suatu daerah agar menghentikan sementara pelaksanaan Shalat Jumat dan Shalat Jamaah di masjid karena adanya kondisi darurat saat ini. Beberapa poin penting fatwa tersebut diantaranya:

1. Sebagaimana adanya laporan kesehatan mengenai bahaya penyebaran dan penularan virus Covid-19 yang sangat cepat di masyarakat dan para penderitanya pun terkadang sulit untuk mendeteksi dan menyadari bahwa dia telah terinfeksi virus Covid-19 yang telah menjadi pandemi global. Untuk itu menjadikan virus ini berpotensi tinggi untuk menularkan setiap orang dan di setiap tempat.

2. Menjaga dan melindungi jiwa dan raga serta berupaya untuk senantiasa menjauh dari segala hal yang membahayakan adalah prinsip utama dari

\footnotetext{
${ }^{3}$ Muhammad Lutfi Hakim, "Pergeseran Paradigma Maqashid Al-Syari'ah Dari Klasik Sampai Kontemporer," Al-Manahij X, no. 1 (2016): 1-16.

${ }^{4}$ Musolli Musolli, "Maqasid Syariah: Kajian Teoritis Dan Aplikatif Pada Isu-Isu Kontemporer," AT-TURAS: Jurnal Studi Keislaman 5, no. 1 (2018): 60-81
}

Published by:

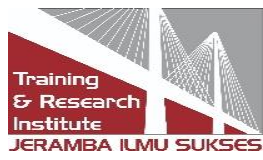


Maqashid Syari'ah. Untuk itu, Hai'ah Kibar Ulama Al-Azhar sebagai suatu lembaga yang memiliki kewenangan untuk menetapkan dan mengeluarkan hukum Syar'i yang berkaitan dengan berbagai masalah yang ada di seluruh penjuru dunia dengan ini memfatwakan bahwa boleh bagi suatu negara atau daerah untuk meniadakan shalat jum'at dan shalat jamaah di masjid untuk sementara waktu, dengan tujuan mencegah penularan dan penyebaran virus, baik dalam skala perseorangan ataupun nasional.

3. Seluruh masjid tetap diwajibkan untuk mengumandangkan adzan setiap waktu shalat. Diperbolehkan pula bagi para muadzin untuk mengumandangkan lafal "Shollu fi buyutikum" yang artinya "shalatlah di rumah-rumah kalian".

4. Bagi mereka yang sakit dan lanjut usia, dianjurkan supaya tetap berada di rumah dan wajib untuk mentaati himbauan dari pihak berwenang di setiap negara, dan tidak keluar rumah untuk melaksanakan shalat jumat maupun shalat jamaah terutama setelah adanya laporan kesehatan yang menunjukkan angka resmi tentang penyebaran dan penularan virus Covid-19.

5. Kemudian bagi para pemerintah di setiap negara dianjurkan agar lebih serius dalam menangani penyebaran dan penularan virus Covid-19. Para ulama telah sepakat bahwa sesuatu yang telah diprediksi kemunculannya pada hakikatnya harus dilakukan pencegahannya. Selain itu, menjaga kesehatan jasmani merupakan bagian dari Maqashid al-Syari'ah dan merupakan tujuan syariat Islam yang utama.

Begitu juga dengan MUI yang mengeluarkan fatwa yang isinya kurang lebih sama dengan poin-poin sebelumnya, yaitu: ${ }^{5}$

1. Setiap orang wajib melakukan ikhtiar menjaga kesehatan dan menjauhi setiap hal yang diyakini dapat menyebabkannya terpapar penyakit, karena hal itu merupakan bagian dari menjaga tujuan pokok beragama (al-Dharuriyat alKhams)

2. Orang yang telah terpapar virus Corona, wajib menjaga dan mengisolasi diri agar tidak terjadi penularan kepada orang lain. Baginya shalat Jumat dapat diganti dengan shalat zuhur di tempat kediaman, karena shalat jumat merupakan ibadah wajib yang melibatkan banyak orang sehingga berpeluang terjadinya penularan virus secara massal. Baginya haram melakukan aktifitas ibadah sunnah yang membuka peluang terjadinya penularan, seperti jamaah shalat lima waktu/ rawatib, shalat Tarawih dan Ied di masjid atau tempat umum lainnya, serta menghadiri pengajian umum dan tabligh akbar.

3. Orang yang sehat dan yang belum diketahui atau diyakini tidak terpapar COVID-19, harus memperhatikan hal-hal sebagai berikut:

a. Dalam hal ia berada di suatu kawasan yang potensi penularannya tinggi atau sangat tinggi berdasarkan ketetapan pihak yang berwenang maka ia boleh meninggalkan salat Jumat dan menggantikannya dengan shalat zuhur di

${ }^{5}$ Fatwa MUI, No.14/2020

Published by:

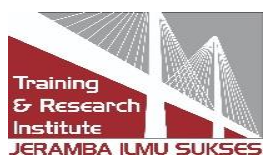


tempat kediaman, serta meninggalkan jamaah shalat lima waktu/rawatib, Tarawih, dan Ied di masjid atau tempat umum lainnya.

b. Dalam hal ia berada di suatu kawasan yang potensi penularannya rendah berdasarkan ketetapan pihak yang berwenang maka ia tetap wajib menjalankan kewajiban ibadah sebagaimana biasa dan wajib menjaga diri agar tidak terpapar virus Corona, seperti tidak kontak fisik langsung (bersalaman, berpelukan, cium tangan), membawa sajadah sendiri, dan sering membasuh tangan dengan sabun.

4. Dalam kondisi penyebaran COVID-19 tidak terkendali di suatu kawasan yang mengancam jiwa, umat Islam tidak boleh menyelenggarakan shalat jumat di kawasan tersebut, sampai keadaan menjadi normal kembali dan wajib menggantikannya dengan shalat zuhur di tempat masing-masing. Demikian juga tidak boleh menyelenggarakan aktifitas ibadah yang melibatkan orang banyak dan diyakini dapat menjadi media penyebaran COVID-19, seperti jamaah shalat lima waktu/ rawatib, shalat Tarawih dan Ied di masjid atau tempat umum lainnya, serta menghadiri pengajian umum dan majelis taklim.

5. Dalam kondisi penyebaran COVID-19 terkendali, umat Islam wajib menyelenggarakan shalat Jumat.

6. Pemerintah menjadikan fatwa ini sebagai pedoman dalam upaya penanggulangan COVID-19 terkait dengan masalah keagamaan dan umat Islam wajib mentaatinya.

7. Pengurusan jenazah (tajhiz janazah) terpapar COVID-19, terutama dalam memandikan dan mengkafani harus dilakukan sesuai protokol medis dan dilakukan oleh pihak yang berwenang, dengan tetap memperhatikan ketentuan syariat. Sedangkan untuk menshalatkan dan menguburkannya dilakukan sebagaimana biasa dengan tetap menjaga agar tidak terpapar COVID-19.

8. Umat Islam agar semakin mendekatkan diri kepada Allah dengan memperbanyak ibadah, taubat, istighfar, dzikir, membaca Qunut Nazilah di setiap shalat fardhu, memperbanyak shalawat, memperbanyak sedekah, dan senantiasa berdoa kepada Allah SWT agar diberikan perlindungan dan keselamatan dari musibah dan marabahaya (doa daf'u al-bala'), khususnya dari wabah COVID-19.

9. Tindakan yang menimbulkan kepanikan dan/atau menyebabkan kerugian publik, seperti memborong dan menimbun bahan kebutuhan pokok dan menimbun masker hukumnya haram.

\section{Meniadakan Shalat Jumat dan Shalat Jamaah}

Hai'iah Kibar Ulama Al-Azhar dan MUI mengeluarkan fatwa yang terkait untuk meniadakan shalat jumat dan shalat jamaah ditujukan untuk memudahkan umat muslim agar tetap dapat melaksanakan ibadah tanpa adanya resiko tertular virus Covid-19 atau memperburuk kondisi yang sudah terinfeksi. Dalam permasalah ini Prof. Dr. Wahbah Az-Zuhaili dalam karyanya yang berjudul Fiqih Islam Wa 
Adilatuhu menjelaskan kebolehan meninggalkan sholat jumat dan sholat berjamaah, diantaranya yaitu: ${ }^{6}$

1. Sakit atau berada pada kondisi yang untuk melaksanakan shlat jama'ah. Sebagaimana dalam firman Allah QS. Al-Hajj ayat 78:

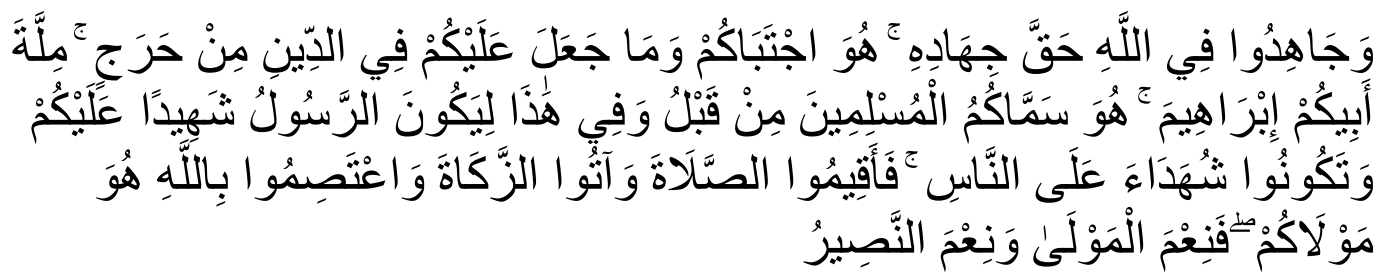

"Dan berjihadlah kamu pada jalan Allah dengan jihad yang sebenar-benarnya. Dia telah memilih kamu dan Dia sekali-kali tidak menjadikan untuk kamu dalam agama suatu kesempitan. (Ikutilah) agama orang tuamu Ibrahim. Dia (Allah) telah menamai kamu sekalian orang-orang muslim ari dahulu, dan (begitu pula) dalam (Al Quran) ini, supaya Rasul itu menjadi saksi atas dirimu dan supaya kaтu semua menjadi saksi atas segenap manusia, maka dirikanlah sembahyang, tunaikanlah zakat dan berpeganglah kamu pada tali Allah. Dia adalah Pelindungmu, maka Dialah sebaik-baik Pelindung dan sebaik-baik Penolong." (QS. AlHajj:78)

2. Takut adanya bahaya

Kewajiban shalat jumat dan shalat jamaah dapat gugur apabila orang tersebut merasa khawatir akan adanya bahaya terhadap dirinya, hartanya, atau mengalami sakit. Sebagaimana hadis yang diriwayatkan Abu Daud: "Orang yang mendengar panggilan, tidak ada yang bisa mencegahnya kecuali udzur. Seseorang bertanya,"Udzur itu apa saja?". Beliau SAW menjawab, "Rasa takut atau sakit." (HR Abu Daud).

\section{Pertimbangan cuaca}

Gugurnya kewajiban shalat jamaah karena adanya pertimbangan cuaca ini sesuai dengan hadis yang dinarasikan oleh Nafi' dengan derajat shahih: "Di suatu malam yang dingin, Ibnu 'Umar mengumandangkan adzan ketika hendak sholat di Dajnan dan mengatakan Salu fi rihaalikum (sholatlah di rumahmu). Dia mengatakan, Rasulullah SAW pernah menyuruh muadzin mengumandangkan Salu fi rihaalikum (sholatlah di rumahmu) saat adzan di malam yang hujan atau sangat dingin dalam perjalanan." (HR Bukhari).

4. Sedang buang hajat

Hal ini bertujuan untuk memudahkan umat Islam dalam melakukan shalat lebih baik dan lebih kusyu'. Sebagaimana hadis yang diriwayatkan oleh Abu Hurairah r.a: Rasulullah SAW berkata, "Ketika tiba waktunya sholat jangan terburu-buru, berjalankan dengan perlahan dan penuh hormat. Apapun yang bisa kamu 2010).

${ }^{6}$ Wahbah Al Zuhaili, Terjemahan Fiqih Islam Wa 'Adillatuhu (Jakarta: Gema Insani Press,

Published by:

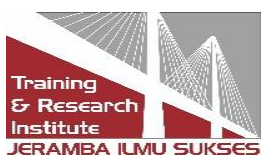


dapatkan maka doakanlah, dan apapun yang dapat diperbaiki makam perbaikilah." (HR An-Nasa'i)

5. Makan sesuatu yang beraroma tidak sedap

Mengonsumsi makanan yang beraroma tajam dan tidak sedap akan berisiko mengeluarkan bau nafas atau bau badan yang kurang sedap. Hal ini yang kemudian dikhawatirkan dapat mengganggu jamaah lain dalam beribadah. Sebagaimana hadis yang dinarasikan oleh Mu'awiyah bin Qurrah dengan derajat shahih. "Rasulullah SAW melarang dua tanaman yaitu bawang putih (garlic) dan bawang bombay (onion) dan dia berkata, "Siapa saja yang makan dua tanaman ini jangan mendekati masjid kami. Jika perlu mengkonsumsi keduanya pastikan termasak sempurna. Keduanya adalah bawang putih dan bawang bombay." (HR. Abu Daud).

6. Tertahan di suatu tempat

Hal in sebagaimana firman Allah dalam QS. Al-Baqarah ayat 286:

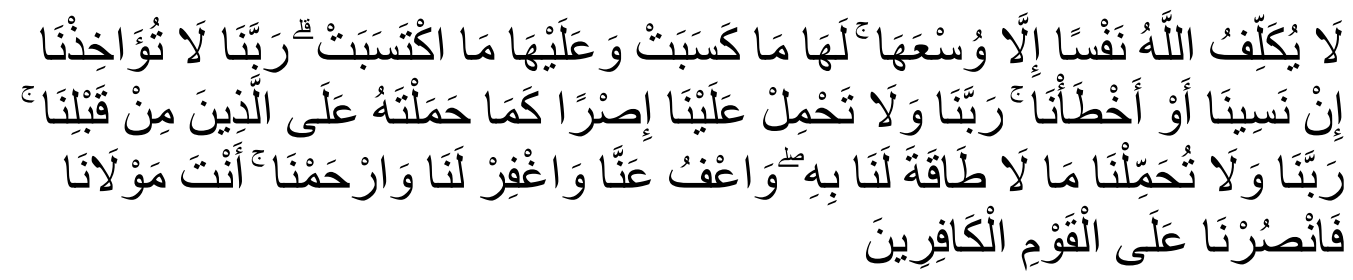

“Allah tidak membebani seseorang melainkan sesuai dengan kesanggupannya. Ia mendapat pahala (dari kebajikan) yang diusahakannya dan ia mendapat siksa (dari kejahatan) yang dikerjakannya. (Mereka berdoa): "Ya Tuhan kami, janganlah Engkau hukum kami jika kami lupa atau kami tersalah. Ya Tuhan kami, janganlah Engkau bebankan kepada kami beban yang berat sebagaimana Engkau bebankan kepada orang-orang sebelum kami. Ya Tuhan kami, janganlah Engkau pikulkan kepada kami apa yang tak sanggup kami memikulnya. Beri maaflah kami; ampunilah kami; dan rahmatilah kami. Engkaulah Penolong kami, maka tolonglah kami terhadap kaum yang kafir" (QS. Al-Baqarah: 286)

Mengenai pertimbangan pengambilan hukum tersebut diperlukan pemahaman Maqashid al-Syari'ah dalam rangka mengetahui masalah dari setiap hukum yang ditetapkan oleh Allah swt. Karena pemahaman maqashid al-syari'ah ini memberikan kontribusi yang besar dalam pengembangan hukum Islam. Yang menjadi pertimbangan gugurnya shalat jumat dan shalat jamaah dapat didasarkan pada argument al-Syathibi seorang tokoh maqashid yang menyatakan bahwa syari'at yang diturunkan oleh syari' adalah untuk mewujudkan kemaslahatan manusia dan menjauhi kemudharatan. Kemaslahatan itu sendiri terbagi menjadi tiga kebutuhan, yaitu dharuriyat (primer), hajiyat (sekunder), dan tahsiniat (tersier).

Dalam konteks wabah virus covid-19, gugurnya shalat jumat dan shalat jamaah merupakan perkara dharuriyat (primer). Kebutuhan dharuriyat ini merupakan kebutuhan pokok yang berkaitan dalam hal mewujudkan dan melindungi eksistensi

Published by:

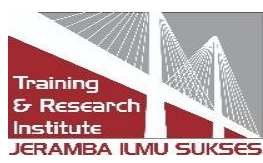


lima hal pokok, yaitu agama, jiwa, akal, keturunan dan harta. Oleh karena itu, apabila kewajiban tersebut tetap dilaksanakan terutama pada daerah yang memiliki potensi tinggi dalam penularan penyakit tersebut, maka dapat menyebabkan potensi adanya kasus penularan lain, karena kedua kewajiban tersebut memancing adanya keramaian dan kerumunan yang seharusnya dihindari selama penyebaran virus. Untuk itu dalam pengambilan hukumnya didasarkan pada 2 cara yaitu: hifdzuha min nahiyah alwujud (menjaga hal-hal yang dapat melanggengkan keberadaannya) dan hifdzuha min nahiyah 'adam (mencegah hal-hal yang dapat dihilangkannya). Contoh dalam kasus ini, untuk menjaga kesehatan atau dapat kita kategorikan al-nafs, maka kita harus mengonsumsi makanan bergizi, menjaga kebersihan, dan melakukkan pola hidup sehat. Dan untuk mencegah hilangnya hal tersebut, kita dianjurkan untuk menghindari kerumunan yang berpotensi mengakibatkan penularan, memakai masker ketika sakit, dan melakukan pemakaman jenazah sesuai dengan anjuran petugas kesehatan yang berwenang.

Sebagaimana yang telah diuraikan sebelumnya bahwa hakikat dari Maqashid alSyari'ah pada dasarnya adalah untuk menciptakan kemaslahatan dan menghindari dari segala macam kemudharatan. Sehingga, semua kasus hukum yang disebutkan secara tegas dalam al-Qur'an dan Sunnah maupun hukum Islam yang dihasilkan melalui proses ijtihad harus didasarkan pada tujuan adanya hukum tersebut, yaitu untuk menciptakan maslahat. ${ }^{7}$

Proses penemuan maslahat oleh para mujtahid, dapat dilakukan melalui berbagai macam metode ijtihad. Intinya metode-metode tersebut bermuara pada upaya penemuan "maslahat" dan menjadikannya sebagai alat untuk menetapkan hukum yang kasusnya tidak disebutkan secara tegas dalam al-Qur'an maupun Sunnah. Terdapat dua metode ijtihad yang dikembangkan oleh para mujtahid dalam upaya menggali dan menetapkan maslahat. Kedua metode tersebut adalah metode Ta'lili (metode analisis substantive) dan metode Istishlahi (Metode Analisis Kemaslahatan. ${ }^{8}$

Metode ta'lili adalah suatu metode analisis hukum dengan melihat kesamaan 'illat atau nilai-nilai substansial dari persoalan tersebut, dengan kejadian yang telah diceritakan dalam nash. Metode yang telah dikembangkan oleh para mujtahid dalam bentuk analisis tersebut adalah qiyas dan istihsan.

Secara etimologi qiyas berarti ukuran, mengetahui ukuran sesuatu, membandingkan atau menyamakan sesuatu dengan sesuatu yang lain. Sedangkan pengertian qiyas secara terminology terdapa beberapa perbedaan pendapat antar para ulama, tetapi mempunyai maksud yang sama. Diantaranya yang dikemukakan oleh 'Abdul Karim Zaidan, menurutnya qiyas adalah "Menyamakan suatu kasus yang tidak terdapat dalam nas dengan suatu kasus yang hukumnya terdapat dalam nas, karena adanya persamaan 'illat dalam kedua kasus hukum tersebut"'

${ }^{7}$ Ali Mutakin, "Teori Maqashid Al Syari'ah Dan Hubungannya Dengan Metode Istinbath Hukum,” Kanun Jurnal Ilmu Hukum 19, no. 3 (2017): 547-70.

${ }^{8}$ Mutakin.

${ }^{9}$ Mutakin.

Published by:

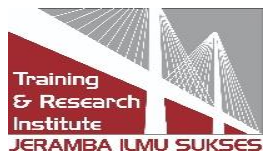


Dari uraian tersebut dapat dipahami bahwa dalam qiyas tersebut terdapat beberapa unsur yang harus terpenuhi, unsur-unsur tersebut adalah 'ashl, far', hukmul al-ashl, dan 'illat. Keempat unsur tersebut lazim disebut dengan rukun qiyas. Pembahasan tentang keempat rukun qiyas tersebut, rukun terakhir adalah 'illat yang merupakan pembahasan paling penting, karena ada atau tidak adanya suatu hukum dalam kasus baru sangat tergantung pada atau tidaknya 'illat pada kasus tersebut. Hal ini berdasarkan pada kaidah al-hukm yadûru ma'a 'illatihî wujûdan wa'adaman (keberadaan hukum itu berkutat pada keberadaan "illat" (sebab)nya. Ada "illat" ada hukum, tak ada "illat" tak ada hukum). Pembahasan Tentang "illat juga perlu dibedakan antara pengertian 'illat dan hikmat. Hikmat adalah manfaat yang tampak ketika Allah memerintahkan sesuatu atau terhindarnya kerusakan ketika Syari' melarang sesuatu. Sedangkan 'illat adalah sifat lahir yang tetap (mudlabit) yang biasanya hikmat terwujud di dalamnya. ${ }^{10}$

Hukum gugurnya kewajiban shalat jumat muncul karena adanya risiko mudharat kepada diri dan orang lain, maka hal tersebut dapat menjadi uzur syariat (sad al dzariah) sehingga dibolehkan untuk meninggalkan shalat jumat berjamaah dengan diganti shalat dhuhur biasa di kediaman masing-masing. Pandangan hukum ini sebagaimana kaidah hukum Al-masyaqqat tajlibu al-taisir (keberatan dapat menjadi sebab bagi suatu kemudahan). Kaidah lain Al-dhararu yuzal, yang artinya bahwa mudharat harus ditinggalkan. Begitu juga kaidah lainnya seperti Ma ubuhuli aldharurah yaqdiru biqadriha (apa yang dibolehkan karena suatu kedaruratan, maka ia hanya boleh sesuai dengan kadar kedarutannya).

Adanya kondisi nyata yang berisiko memicu mudharat kesehatan bagi diri sendiri dan orang lain di tengah penyebaran wabah Covid-19, hal inilah yang dapat dijadikan 'illat atau hal yang bersifat substansial yang mempengaruhi adanya suatu hukum. Contohnya sebagaimana dalam QS At-Taubah ayat 122:

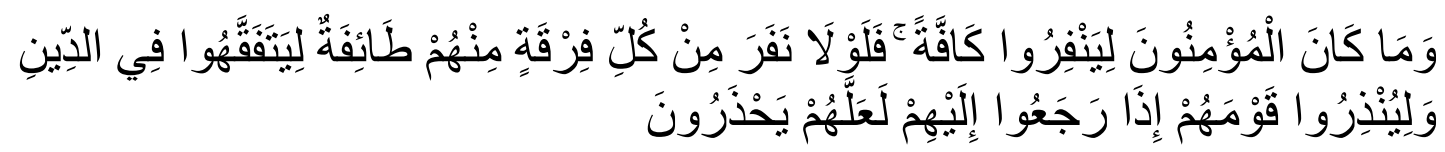

"Tidak sepatutnya bagi mukminin itu pergi semuanya (ke medan perang). Mengapa tidak pergi dari tiap-tiap golongan di antara mereka beberapa orang untuk memperdalam pengetahuan mereka tentang agama dan untuk memberi peringatan kepada kaumnya apabila mereka telah kembali kepadanya, supaya mereka itu dapat menjaga dirinya." (QS. At-Taubah: 122)

Dalam ayat tersebut dijelaskan bahwa Allah swt melarang agar tidak semua orang mukmin terjun ke medan perang, karena hendaknya ada sebagian dari mereka yang menghidupkan dakwah dan menyebarkan ilmu. Apabila hal ini kita qiyas-kan dengan penyebaran wabah penyakit Covid19, maka dapat dipahami bahwa uzur syariat yang menyebabkan orang sakit boleh meninggalkan shalat jumat berjamaah juga dapat diambil oleh orang yang tidak sakit namun berisiko tinggi terinfeksi virus tersebut. Para pakar kesehatan telah menerangkan bahwa di antara cara meminimalisir risiko

${ }^{10}$ Mutakin.

Published by:

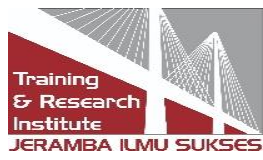


penyebaran virus adalah dengan melakukan social distancing, dengan tujuan menghindarkan titik-titik keramaian dan kerumunan orang yang di antaranya terjadi pada shalat jumat.

Dari penjelasan tersebut dapat dipahami bahwa shari'at Islam diturunkan oleh Allah dan Rasul-Nya, selalu berdasarkan pada sifat keadilan, kemaslahatan dan selaras dengan akal sehat, maka dari itu qiyas sebagai salah satu metode penetapan hukum hendaknya mengacu pada prinsip-prinsip tersebut yang pada intinya tidak bertentangan dengan Maqashid al-Syari'ah akan tetapi berusaha untuk merealisasikan Maqashid al-Syari'ah itu sendiri.

\section{Penutup}

Dalam konteks wabah virus covid-19, gugurnya shalat jumat dan shalat jamaah merupakan perkara dharuriyat (primer). Kebutuhan dharuriyat ini merupakan kebutuhan mendasar yang menyangkut dalam mewujudkan dan melindungi eksistensi lima hal pokok, yaitu agama, jiwa, akal, keturunan dan harta. Oleh karena itu, apabila kewajiban tersebut tetap dilaksanakan terutama pada daerah yang memiliki potensi tinggi dalam penularan penyakit tersebut, maka dapat menyebabkan potensi adanya kasus penularan lain, karena kedua kewajiban tersebut memancing adanya keramaian dan kerumunan yang seharusnya dihindari selama penyebaran virus. Hukum gugurnya kewajiban shalat jumat muncul karena adanya risikio mudharat kepada diri dan orang lain, maka hal tersebut dapat menjadi uzur syariat (sad al dzariah) sehingga dibolehkan untuk meninggalkan shalat jumat berjamaah dengan diganti shalat dhuhur biasa di kediaman masing-masing. Adanya kondisi nyata yang berisiko memicu mudharat kesehatan bagi diri sendiri dan orang lain di tengah penyebaran wabah Covid-19, hal inilah yang dapat dijadikan 'illat atau hal yang bersifat substansial yang mempengaruhi adanya suatu hukum.

\section{Referensi}

Zuhaili, Wahbah Al. Terjemahan Fiqih Islam Wa 'Adillatuhu. Jakarta: Gema Insani Press, 2010.

Hakim, Husnul. 'Epidemi Dalam Al-Qur'an (Suatu Kajian Tafsir Maudhu'i Dengan Corak Ilmi)." KORDINAT 17, no. 1 (2018): 113-27.

H, Galuh Nashrullah Kartika Mayangsari, and H. Hasni Noor. "Konsep Maqashid Al-Syari'ah Dalam Menentukan Hukum Islam (Perspektif Al-Syatibi Dan Jasser Auda)." Jurnal Ekonomi Syariah Dan Hukum Ekonomi Syariah 1, no. 1 (2014): 5069.

Jauhari, Iman. "Kesehatan Dalam Pandangan Hukum Islam." Kanun: Jurnal Ilmu Hukum 13, no. 3 (2011): 33-58

Mutakin, Ali. "Teori Maqashid Al Syari'ah Dan Hubungannya Dengan Metode Istinbath Hukum.” Kanun Jurnal Ilmu Hukum 19, no. 3 (2017): 547-70.

Wijaya, Abdi. "Cara Memahami Maqashid Al- Syari'Ah.” Jurnal Aj-Daulah 4, no. 2 (2015): 344-53. 
Shidiq, Ghofar. "Teori Maqashid Al-Syari'ah Dalam Hukum Islam.” Sultan Agung 25, no. 118 (2009): 117-30.

Musolli, Musolli. "Maqasid Syariah: Kajian Teoritis Dan Aplikatif Pada Isu-Isu Kontemporer.” AT-TURAS: Jurnal Studi Keislaman 5, no. 1 (2018): 60-81.

Wijayanti, S., and T. Lailam. "Implikasi Pengujian Undang-Undang Oleh Mahkamah Konstitusi Dalam Mewujudkan Maqashid Syari'ah." Media Hukum 25, no. 2 (2018): 202-16.

Susilawati, Nilda. "Stratifikasi Al-Maqasid Al-Khamsah Dan Penerapannya Dalam Al-Dharuriyat, Al-Hajiyat, Al-Tahsiniyat.” Mizani 9, no. 1 (2015): 137-50.

Hakim, Muhammad Lutfi. "Pergeseran Paradigma Maqashid Al-Syari'ah Dari Klasik Sampai Kontemporer.” Al-Manahij X, no. 1 (2016): 1-16.

\section{Copyrights}

Copyright for this article is retained by the author(s), with first publication rights granted to the journal.

This is an open-access article distributed under the terms and conditions of the Creative Commons Attribution license (http://creativecommons.org/licenses/by/4.0/) 